[Regular Paper]

\title{
High-rate Fermentation of Acetate to Methane under Saline Condition by Aceticlastic Methanogens Immobilized in Marine Sediment
}

\author{
Akihisa KITA $^{\dagger 1), \dagger 3)}$, Kounosuke KoBAYASHI ${ }^{\dagger 1)}$, Toyokazu MIURA ${ }^{\dagger 1), \dagger 3)}$, Yoshiko OKAmURA ${ }^{\dagger 1), \dagger 3)}$, \\ Tsunehiro AKI ${ }^{\dagger 1), \dagger 3)}$, Yukihiko MatsumURA ${ }^{\dagger 2), \dagger 3)}$, Takahisa TAJIMA ${ }^{\dagger 1), \dagger 3)}$, \\ Naomichi NisHIO ${ }^{\dagger 1}$, and Yutaka NAKASHIMADA $\left.{ }^{\dagger 1} *, \dagger 3\right)$ \\ †1) Dept. of Molecular Biotechnology, Graduate School of Advanced Sciences of Matter, Hiroshima University, \\ 1-3-1 Kagamiyama, Higashi-Hiroshima, Hiroshima 739-8530, JAPAN \\ $\dagger 2$ Div. of Energy and Environmental Engineering, Hiroshima University, \\ 1-4-1 Kagamiyama, Higashi-Hiroshima, Hiroshima 739-8527, JAPAN \\ $\dagger 3)$ CREST, Japan Science and Technology Agency, 7 Goban-cho, Chiyoda-ku, Tokyo 102-0076, JAPN
}

(Received July 28, 2015)

\begin{abstract}
High-rate production of methane from acetate using a fixed-bed reactor filled with marine sediment containing halotolerant aceticlastic methanogens and $3 \% \mathrm{NaCl}$ was investigated. In continuous culture, the methane production rate increased with increasing dilution rate. The maximum methane production rate of $750 \mathrm{mM} \mathrm{d}^{-1}$ was observed at a dilution rate of $16.2 \mathrm{~d}^{-1}$, which is impossible without immobilization of the cells in the sediment. Using scanning electron microscopy, we observed Methanosaeta-like filamentous microorganisms and Methanosarcina-like coccoid microorganisms in granule-like structures. The results demonstrated that marine sediment is not only a promising microbial resource of halophilic aceticlastic methanogens, but also a supporting material to fix aceticlastic methanogens in a fixed-bed reactor.
\end{abstract}

\section{Keywords}

Methane, Acetate, Aceticlastic methanogen, Fixed-bed reactor, Saline condition

\section{Introduction}

Methane fermentation is employed worldwide for organic waste treatment and energy recovery from various kinds of organic matter including manure, food, and municipal wastes. However, methane fermentation using common anaerobic technologies in saline condition $(>3 \%)$ is often difficult because of inhibitory effect by salinity ${ }^{1) \sim 7)}$.

Methane fermentation occurs in complex microbial ecosystems, in which organic matter is converted to methane in three steps: hydrolysis/acidogenesis, acetogenesis, and methanogenesis ${ }^{8)}$. In the first step, organic matter is converted to volatile fatty acids (VFAs) by various bacteria. Then, VFAs such as propionate and butyrate are converted to acetate and hydrogen by propionate- and butyrate-oxidizing bacteria, respectively. The final step of methane fermentation, formation of methane from $\mathrm{CO}_{2}$ with $\mathrm{H}_{2}$ is promoted by the activity of hydrogenotrophic methanogens, whereas acetate degradation can proceed through two different path-

DOI: dx.doi.org/10.1627/jpi.59.9

* To whom correspondence should be addressed.

* E-mail: nyutaka@hiroshima-u.ac.jp ways: direct cleavage of acetate by aceticlastic methanogens or syntrophic acetate oxidation $(\mathrm{SAO})^{9)}$. The aceticlastic methanogens cleavage methyl group of acetate into methane, while the carboxyl group is converted into $\mathrm{CO}_{2}{ }^{10)}$. On the other hand, SAO is a twostep reaction in which acetate is primarily oxidized to $\mathrm{H}_{2}$ and $\mathrm{CO}_{2}$ by $\mathrm{SAO}$ bacteria, followed by the subsequent reduction of $\mathrm{CO}_{2}$ with $\mathrm{H}_{2}$ to methane by hydrogenotrophic methanogens (SAO-HM pathway) $)^{9}$.

It has been reported that most of the methane (approximately 65-80\%) generated from fermentation is derived from direct cleavage of acetate by aceticlastic methanogens ${ }^{9), 11) ~ 13)}$. However, recent studies have reported a significant contribution by SAO-HM pathway to the production of methane under inhibitory conditions such as the level of ammonium-nitrogen, acetate concentration, or the synergetic stress of acids and ammonium, dilution rate, temperature and prevailing methanogenic population structure ${ }^{9), 10), 14) . ~ N e v e r t h e l e s s, ~}$ it is generally assumed that direct cleavage of acetate is important and predominant pathway though depending on the environmental conditions. Hence, aceticlastic methanogens play an important role in methane fermentation. Only two genera, Methanosarcina and Methanosaeta, are known to be aceticlastic methano- 
gens ${ }^{15)}$. Unlike Methanosarcina, which prefers methylated compounds such as methanol and methylamines to acetate, Methanosaeta is a specialist that uses only acetate $^{15)}$.

Optimal design of an anaerobic digester for high-rate methane fermentation is important to achieve high organic loading rate, reduced hydraulic retention time (HRT), and high methane yields ${ }^{16)}$. In this context, one- or two-stage digesters have been employed. In one-stage digestion, all microbiological phases of anaerobic digestion occur in one tank. However, conditions that are favorable to the growth of acid-forming bacteria such as short HRT and low pH, may be inhibitory to methane-forming bacteria ${ }^{17)}$. On the other hand, in a two-stage system, different microbial phases are separated. In such systems, the hydrolytic and acidification phases may occur in the first reactor, while acetogenesis and methanogenesis occur in the second reactor. The concept of two-stage digestion is driven by separate optimization of each step, in which different types of microorganisms with different physiology participate. Therefore, two-stage system has several advantages over conventional one-phase processes, such as increased stability of the process by controlling the acidification-phase in order to prevent overloading and the build-up of toxic material, and higher organic loading rates and shorter HRT, resulting in potentially higher yields of biogas in smaller digesters than in one-stage reactors ${ }^{16), 17)}$.

Application of marine aceticlastic methanogens for conventional processes in a second reactor in two-stage digestion would enable treatment of organic wastes with high salinity ${ }^{6), 18), 19)}$. We recently reported that the aceticlastic methanogen Methanosaeta sp. starin $\mathrm{H}_{\mathrm{A}}$, highly enriched from marine sediment collected from Hiroshima Bay, exhibited growth at $2.06 \mathrm{M}$ (corresponding to $12 \%) \mathrm{NaCl}^{20}$. Therefore, we investigated continuous methane production from acetate by enriched Methanosaeta sp. strain $\mathrm{H}_{\mathrm{A}}$ in a glass column reactor packed with a polypropylene-ceramic mixture as support material for fixation of Methanosaeta ${ }^{20)}$. In this set-up, methane production rate under $3 \% \mathrm{NaCl}$ was $70 \mathrm{mM} \mathrm{d}^{-1}$. However, we had previously reported that microbial consortia in coastal mud sediment produced methane from acetate originating from organic matter in the sediment at the higher rate of $96 \mathrm{mM} \mathrm{d}^{-1}$ under $3 \% \mathrm{NaCl}^{21)}$. This suggested that inorganic, small silt in the sediment is a promising candidate for fixing aceticlastic methanogens, allowing higher methane production from acetate than artificial support carriers. However, since the acetate concentration was limited to the amount of organic matter in the marine sediment, the potential of the sediment as support material was not fully characterized.

Therefore, in this study, we attempted high-rate of methane from acetate with acclimated aceticlastic methan- ogens derived from marine sediment under $3 \% \mathrm{NaCl}$.

\section{Materials and Methods}

\section{1. Source of Inoculum and Culture Media}

Marine sediment was collected from the coastal seabed of Hiroshima Bay as reported previously ${ }^{21)}$. The sediment samples were refrigerated at $4{ }^{\circ} \mathrm{C}$ until use. Artificial seawater containing $30 \mathrm{~g} \mathrm{NaCl}, 3.0 \mathrm{~g} \mathrm{MgSO}_{4}$. $7 \mathrm{H}_{2} \mathrm{O}$, and $0.053 \mathrm{~g} \mathrm{CaCl}_{2} \cdot 5 \mathrm{H}_{2} \mathrm{O}$ per $\mathrm{L}$ of deionized water was used for acclimatization of the anaerobic marine sediment microbiota. The $\mathrm{pH}$ of the artificial seawater was adjusted to 8.0 with $1 \mathrm{M} \mathrm{NaOH}$. Basal medium was employed for all experiments except for the acclimatization. The composition of the basal medium was as follows: $0.3 \mathrm{~g} \mathrm{KH}_{2} \mathrm{PO}_{4}, 1.0 \mathrm{~g} \mathrm{NH}_{4} \mathrm{Cl}$, $0.1 \mathrm{~g} \mathrm{MgCl}_{2} \cdot 6 \mathrm{H}_{2} \mathrm{O}, 0.08 \mathrm{~g} \mathrm{CaCl}_{2} \cdot 2 \mathrm{H}_{2} \mathrm{O}, 4 \mathrm{~g} \mathrm{KHCO}_{3}$, $30 \mathrm{~g} \mathrm{NaCl}, 5.0 \mathrm{~g}$ sodium acetate, $1.0 \mathrm{mg}$ resazurin, $10 \mathrm{~mL}$ vitamin solution, and $10 \mathrm{~mL}$ trace element solution. The vitamin solution contained $2.0 \mathrm{mg}$ biotin, $2.0 \mathrm{mg}$ folic acid, $10.0 \mathrm{mg}$ pyridoxine $\mathrm{HCl}, 5.0 \mathrm{mg}$ thiamine $\mathrm{HCl} \cdot 2 \mathrm{H}_{2} \mathrm{O}, 5.0 \mathrm{mg}$ riboflavin, $5.0 \mathrm{mg}$ nicotinic acid, $5.0 \mathrm{mg}$ calcium-D-pantothenate, $5.0 \mathrm{mg}$ p-aminobenzoic acid, $5.0 \mathrm{mg}$ lipoic acid, and $0.1 \mathrm{mg}$ vitamin $\mathrm{B}_{12}$. The trace element solution contained $12.8 \mathrm{~g}$ nitrilotriacetic acid, $1.35 \mathrm{~g} \mathrm{FeCl}_{3} \cdot 6 \mathrm{H}_{2} \mathrm{O}, 0.10 \mathrm{~g} \mathrm{MnCl}_{2} \cdot 4 \mathrm{H}_{2} \mathrm{O}$, $0.024 \mathrm{~g} \mathrm{CoCl}_{2} \cdot 6 \mathrm{H}_{2} \mathrm{O}, 0.10 \mathrm{~g} \mathrm{CaCl}_{2} \cdot 2 \mathrm{H}_{2} \mathrm{O}, 0.10 \mathrm{~g}$ $\mathrm{ZnCl}_{2}, 0.025 \mathrm{~g} \mathrm{CuCl}_{2} \cdot 2 \mathrm{H}_{2} \mathrm{O}, 0.01 \mathrm{~g} \mathrm{H}_{3} \mathrm{BO}_{3}, 0.024 \mathrm{~g}$ $\mathrm{Na}_{2} \mathrm{MoO}_{4} \cdot 2 \mathrm{H}_{2} \mathrm{O}, 1.0 \mathrm{~g} \mathrm{NaCl}, 0.12 \mathrm{~g} \mathrm{NiCl}_{2} \cdot 6 \mathrm{H}_{2} \mathrm{O}$, and $0.026 \mathrm{~g} \mathrm{Na}_{2} \mathrm{SeO}_{3} \cdot 5 \mathrm{H}_{2} \mathrm{O}$.

\section{2. Continuous Culture in a Fixed-bed Reactor}

The marine sediment was acclimated to stimulate methane production. Hereto, batch culture was performed in 700-mL vials using artificial seawater at $37{ }^{\circ} \mathrm{C}$ for approximately six months. After acclimation, the sediment was transferred $[30 \%(\mathrm{v} / \mathrm{v})$ inoculum] into a column reactor with a gas-liquid-solid separator and with a volume of $640 \mathrm{~mL}$ (Fig. 1). Continuous culture was performed in basal medium with $3 \% \mathrm{NaCl}$, with an initial dilution rate of $2.0 \mathrm{~d}^{-1}$. The dilution rate was gradually increased during culture.

\section{3. Batch Culture}

After continuous culture of the marine sediment in the reactor, the sediment was harvested and inoculated [30\% (v/v) inoculum] in 120 -mL serum vials containing basal medium without acetate, and incubated at $37^{\circ} \mathrm{C}$. After the acetate was completely consumed, the sediment was used as inoculum.

To measure the specific growth rate of aceticlastic methanogens in the sludge, triplicate cultures $[10 \%(\mathrm{v} / \mathrm{v})$ inoculum] in $120-\mathrm{mL}$ serum vials containing $50 \mathrm{~mL}$ of basal medium with $5 \mathrm{~g} \mathrm{~L}^{-1}$ of sodium acetate were employed, and the amount of methane produced in the logarithmic growth phase (within 7 days) was measured. To test the effect of the acetate concentration on the 


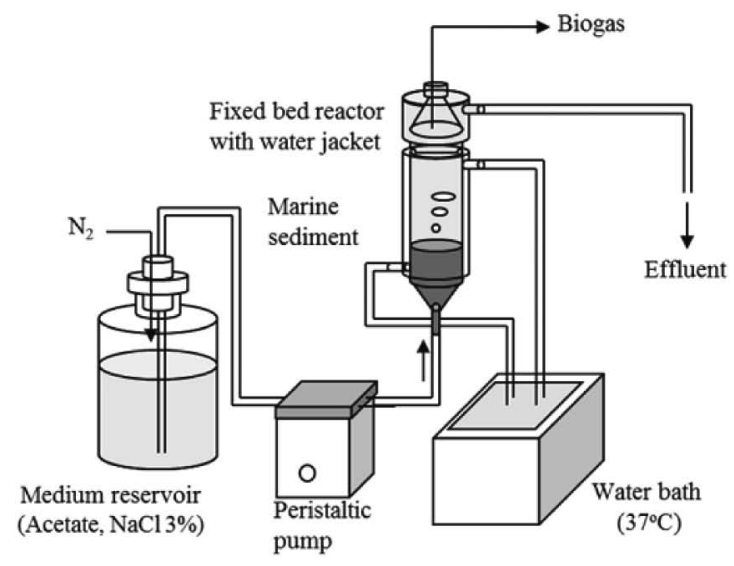

(A)

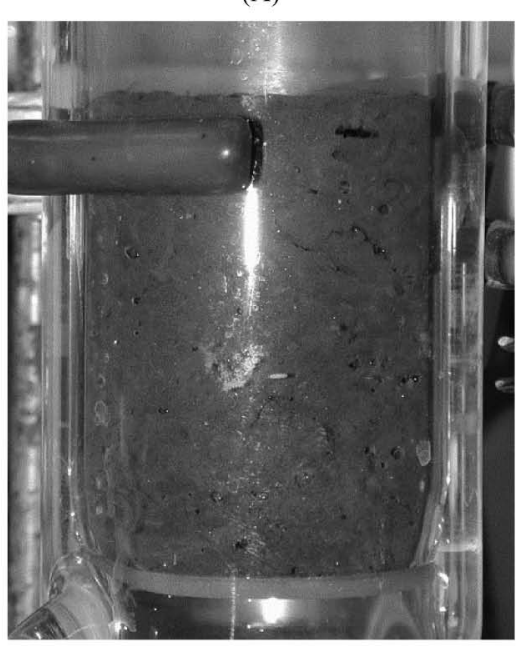

(B)

Fig. 1 Fixed-bed Reactor System for Methane Fermentation of Acetate under High Salinity (A), and the Picture of Sediments during the Culture in the Reactor (B)

specific growth rate, the acetate concentration in the basal medium was varied from 0.5 to $200 \mathrm{mM}$ and batch culture was performed as described above. Mixed liquor volatile suspended solid (MLVSS) was determined as described previously ${ }^{22)}$. Specific growth rates $\left(\mu \mathrm{CH}_{4}\right)$ were calculated during the exponential phase, as described previously ${ }^{22), 23)}$.

\section{4. Scanning Electron Microscopy (SEM)}

For SEM, acclimated sludge was sampled from the reactor after completion of continuous culture. The solid fraction including cells was harvested by centrifugation at $10,000 \times \mathrm{g}$ for $10 \mathrm{~min}$, washed three times with $0.1 \mathrm{M}$ phosphate buffer ( $\mathrm{pH} 7.2$ ), and fixed with $2.5 \%$ glutaraldehyde in $0.05 \mathrm{M}$ phosphate buffer (pH 7.2) for $2 \mathrm{~h}$ at $4{ }^{\circ} \mathrm{C}$. The sample was again washed three times with $0.1 \mathrm{M}$ phosphate buffer ( $\mathrm{pH} 7.2)$, fixed with a $2 \%$ solution of osmium tetraoxide for $2 \mathrm{~h}$ at $4{ }^{\circ} \mathrm{C}$, and dehydrated by successive transfer to $50,70,80,90,95$, and $99.5 \%$ solutions of ethanol and $t$-butyl alcohol. Subsequently, the sample was freeze-dried, mounted on stubs of a scanning microscope with patina paint, and sputter-coated with gold. The sections were examined and photographed using a JSM-5900 SEM (JEOL Ltd., Tokyo, Japan).

\section{5. Chemical Analysis}

The volume of $\mathrm{CH}_{4}$ generated during culture of methanogens was measured by displacing the gas with a saturated solution of $\mathrm{NaCl}$. The concentration of methane was analyzed by gas chromatography (GC-8A; Shimadzu Corp., Kyoto, Japan) equipped with a thermal conductivity detector and a stainless steel column packed with activated carbon, at $70{ }^{\circ} \mathrm{C}$. Argon was used as the carrier gas $^{4}$. The concentration of acetate was quantified by high-performance liquid chromatography (LC-2000 Plus HPLC; JASCO Corp., Tokyo, Japan) equipped with a refractive index detector (RI2031 Plus; JASCO Corp.), Shodex RSpak KC-811 column (Showa Denko K.K., Kanagawa, Japan), and a guard column (Shodex RSpak KC-G; Showa Denko K.K.) at $60{ }^{\circ} \mathrm{C}$. Ultrapure water containing $0.1 \%$ (v/v) phosphoric acid was used as the mobile phase at a flow rate of $0.7 \mathrm{~mL} / \mathrm{min}^{4)}$.

\section{Results and Discussion}

\section{1. Effect of the Dilution Rate on the Methane Production Rate}

Continuous culture in the fixed-bed reactor packed with acclimated marine sediment containing $3 \% \mathrm{NaCl}$ was performed with basal medium containing acetate as the sole carbon source at $37^{\circ} \mathrm{C}$ at a low dilution rate (Fig. 2(A)). The initial dilution rate was $2.0 \mathrm{~d}^{-1}$. When the dilution rate was increased stepwise to $4.9 \mathrm{~d}^{-1}$, the acetate removal efficiency was maintained at ca. $97 \%$ (Fig. 3(A)), and the methane production rate increased in proportion to the increasing dilution rate (Fig. 3(B)). The methane production rate reached $303 \mathrm{mM} \mathrm{d}^{-1}$ at $4.9 \mathrm{~d}^{-1}$ dilution rate. In aceticlastic cleavage of acetate by aceticlastic methanogens, the methyl group of acetate is converted into methane, while the carboxyl group is converted into $\mathrm{CO}_{2}{ }^{10)}$, i.e., $1 \mathrm{~mol}$ of acetate is converted into $1 \mathrm{~mol}$ of methane and $1 \mathrm{~mol}$ of $\mathrm{CO}_{2}$ theoretically. In this study, the ratio of methane production to acetate consumption was approximately equal (Fig. 3(C)) at this dilution rate, indicating that consumed acetate was completely converted to methane by the acclimated methanogenic sediment. To investigate the potential of the acclimated methanogenic sediment at high dilution rate, the dilution rate was gradually increased to $20 \mathrm{~d}^{-1}$ after treatment at $5 \mathrm{~d}^{-1}$ for 20 days (Fig. 2(B)). As the dilution rate increased, the acetate removal rate decreased (Fig. 3(A)). In contrast, the methane production rate increased step-wise until the dilution rate reached $16.2 \mathrm{~d}^{-1}$, but decreased subsequently (Fig. 3(B)). Similar to the low dilution rate conditions, the ratios of 

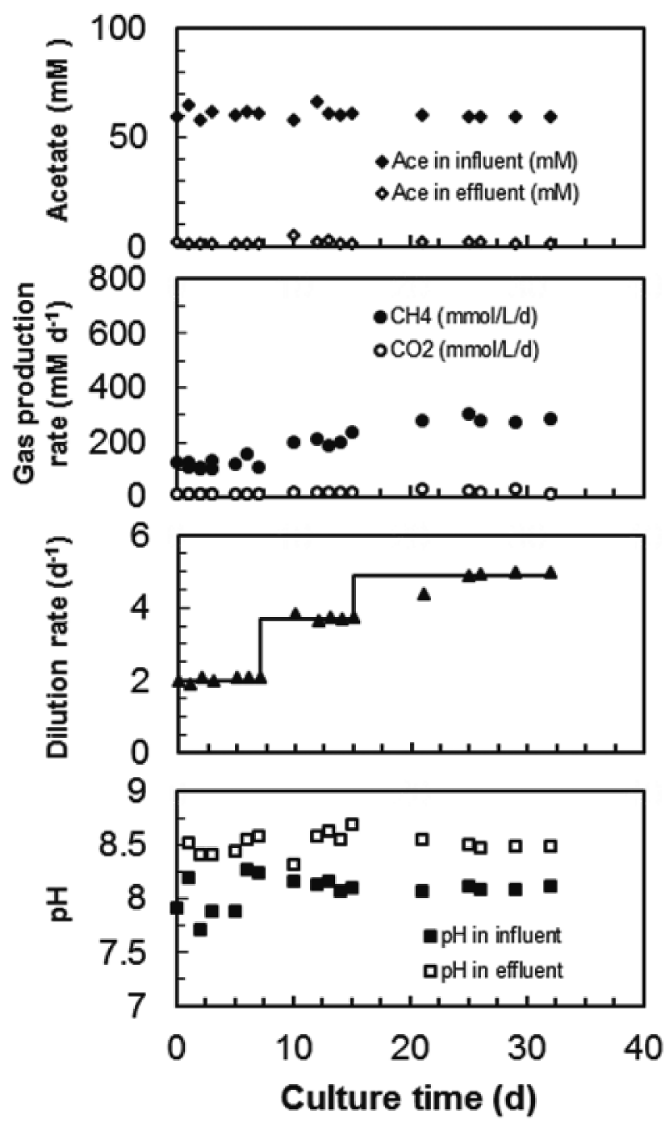

(A)
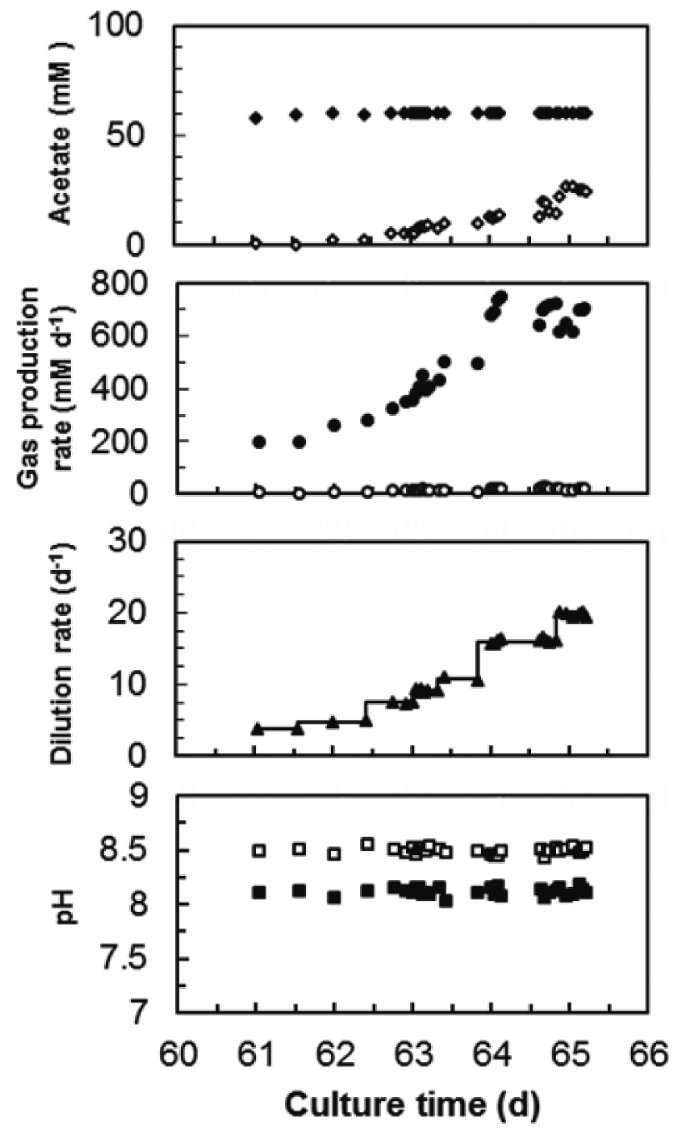

(B)

Symbols: closed diamond, acetate in the influent; open diamond, acetate in the effluent; closed circle, methane production rate; open circle, carbon dioxide production rate; closed triangle, dilution rate; closed square, $\mathrm{pH}$ in the influent; open square, $\mathrm{pH}$ in the effluent.

Fig. 2 Continuous Methane Production from Acetate under $3 \% \mathrm{NaCl}$ in the Fixed-bed Reactor at 2-5 d ${ }^{-1}$ (A) and 4-20 d $\mathrm{d}^{-1}$ Dilution Rates after Acclimation of the Sediment for 60 Days (B)

methane production and acetate consumption were approximately equal at the high dilution rate (Fig. 3(C)).

In this study, a maximum methane production rate of $750 \mathrm{mM} \mathrm{d}^{-1}$ with $77 \%$ of acetate removal rate in $3 \%$ $\mathrm{NaCl}$ was observed at a dilution rate of $16.2 \mathrm{~d}^{-1}$. In our previous study, a maximum methane production rate of $96 \mathrm{mM} \mathrm{d}^{-1}$ was achieved in a UASB reactor using acclimated methanogenic sludge from marine sediment under $3 \% \mathrm{NaCl}$, with a dilution rate of $2.8 \mathrm{~d}^{-1}$ and an acetate removal rate of $55 \%^{21)}$. Therefore, these results suggested that the performance of methane production by acclimated methanogenic sediment in $3 \% \mathrm{NaCl}$ has been dramatically improved in this study. Furthermore, methane production rate when using moving bed biofilm reactor (MBBR) and thermophilic down-flow anaerobic packed-bed reactor (TDPR) under condition without $\mathrm{NaCl}$ addition have been reported to be $183 \mathrm{mM} \mathrm{d}^{-1}$ and $598 \mathrm{mM} \mathrm{d}^{-1}$, respectively (Table 1). Hence, the maximum methane production rate of
$750 \mathrm{mM} \mathrm{d}^{-1}$ in this study was significantly higher than that of other reported conditions, demonstrating that the fixed bed reactor process with marine sediment as the support carrier was useful for efficient methane production from acetate.

\section{2. Characteristics of Acclimated Aceticlastic Methanogens}

In the batch culture of the acclimated marine sediment to investigate the specific growth rates $\left(\mu \mathrm{CH}_{4}\right)$ of acclimated aceticlastic methanogens under $3.0 \% \mathrm{NaCl}$, a maximum specific growth rate of $0.152 \mathrm{~h}^{-1}$ was obtained. The specific growth rate of the acclimated methanogen was higher than that of other known methanogens (Table 2).

To examine the acetate consumption under $3 \%$ $\mathrm{NaCl}$, the initial acetate concentration was varied from 0.5 to $200 \mathrm{mM}$. In the batch culture, the acetate was completely converted to methane in all conditions. Furthermore, when the initial acetate concentration was 

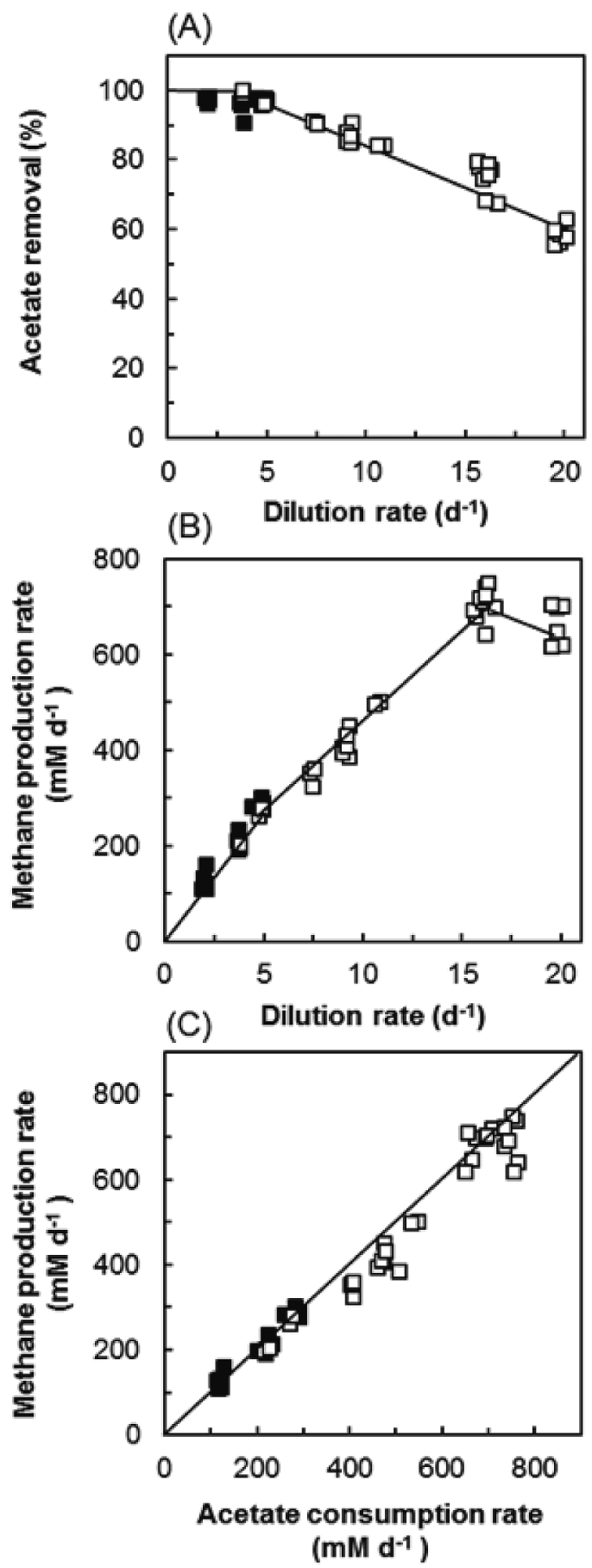

Closed and open squares represent data from the experiments in Figs. 2(A) and 2(B), respectively.

Fig. 3 Efficiency of Acetate Removal (A) and Methane Production Rate (B) at Various Dilution Rates, and Methane Production Rate at Various Acetate Consumption Rates (C)

$150 \mathrm{mM}$, the specific acetate-consumption activity was

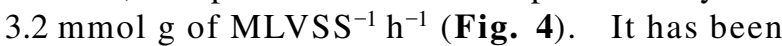
reported that Methanosarcina barkeri shows $0.7 \mathrm{mmol}$ $\mathrm{CH}_{4} \mathrm{~g}$ of $\mathrm{MLVSS}^{-1} \mathrm{~h}^{-1}$ at $30 \mathrm{mM}$ of initial acetate concentration $^{22)}$. Therefore, these results indicated that this acclimated methanogenic sediment possessed high acetate-consumption activity.

\section{3. SEM of Acclimated Marine Sedimnent}

SEM photographs of acclimated marine sediment derived from the fixed-bed reactor with acetate as a sole carbon source and with $3 \% \mathrm{NaCl}$ are shown in Fig. 5 . Granule-like-structures were observed in the sediment (Fig. 5(A)). In the granule-like structures, Methanosaeta-like filamentous microorganisms (Fig. 5(B)) and Methanosarcina-like coccoid microorganisms (Fig. 5(C)) were observed.

Few species of halophilic Methanosarcina have been reported so far. The optimal $\mathrm{NaCl}$ range for growth of the halophilic aceticlastic methanogen Methanosarcina acetivorans was reported to be 0.1-0.6 M (corresponding to $0.6-3.5 \%$ ), and no growth occurred without $\mathrm{NaCl}^{24)}$. Methanosarcina mazei strain Gö1 was able to grow at a concentration of $18,000 \mathrm{mg} \mathrm{Na}^{+} \mathrm{L}^{-1}(4.6 \%$ of $\mathrm{NaCl}$ equivalent $)^{25), 26)}$. In contrast, only two species of halophilic and halotolerant Methanosaeta have been reported $^{20), 27)}$. Aceticlastic halophilic Methanosaeta pelagica $03 \mathrm{~d} 30 \mathrm{qT}$, isolated from tidal flat sediment, were able to grow at $\mathrm{Na}^{+}$concentrations of 0.20 to $0.80 \mathrm{M}$ (1.2 to $4.7 \%$ of $\mathrm{NaCl}$ equivalent), with optimum growth at $0.28 \mathrm{M}(1.6 \% \text { of } \mathrm{NaCl} \text { equivalent })^{27)}$.

We previously enriched and identified aceticlastic halotolerant Methanosaeta $\mathrm{sp}$. strain $\mathrm{H}_{\mathrm{A}}$ from the same marine sediment as that used in this study ${ }^{20)}$. The morphology of this strain was quite similar to the Methanosaeta-like microorganisms observed by SEM in this study; however, the growth rate was lower than that of acclimated methanogens. Hence, we speculated that the collaboration between Methanosarcina and Methanosaeta resulted in the high-performance methane fermentation under saline condition.

\section{Conclusion}

High-rate production of methane from acetate under $3 \% \mathrm{NaCl}$ was successfully achieved using continuous culture in a fixed-bed reactor with marine sediment as the microbial resource of halophilic aceticlastic methanogens and as support material. In continuous culture, a maximum methane production rate of $750 \mathrm{mM} \mathrm{d}^{-1}$ with $77 \%$ acetate removal rate was observed at a dilution rate of $16.2 \mathrm{~d}^{-1}$. Both Methanosaeta- and Methanosarcina-like microorganisms were observed in granule-like structures in the sediment. Our results indicated that acclimated methanogenic marine sediment might be applicable to high-rate methane production from acetate under saline condition.

\section{Acknowledgment}

Part of the study was supported by the Core Research for Evolutional Science and Technology (CREST) Program, through the Japan Science and Technology 
Table 1 Methane Production Rate of Different Conditions

\begin{tabular}{clcccc}
\hline Temp. $^{\text {a) }}$ & \multicolumn{1}{c}{ Reactor } & $\begin{array}{c}\text { Concentration of } \\
\mathrm{NaCl}[\%]\end{array}$ & $\begin{array}{c}\text { Methane production } \\
\text { rate }\left[\mathrm{mM} \mathrm{d}^{-1}\right]\end{array}$ & $\begin{array}{c}\text { Acetate removal } \\
{[\%]}\end{array}$ & Reference \\
\hline M & UASB & 3.5 & $19^{\mathrm{b}), \mathrm{c})}$ & $\mathrm{ND}^{\mathrm{d})}$ & $1)$ \\
M & UASB & 2.5 & $63^{\mathrm{b}), \mathrm{c})}$ & $\mathrm{ND}^{\mathrm{d})}$ & $1)$ \\
M & Fixed-bed reactor & 3.0 & 0 & 56 & $21)$ \\
M & MBBR & 0 & $183^{\mathrm{b})}$ & 97 & $10)$ \\
T & TDAPR & 3.0 & $598^{\mathrm{b})}$ & $65^{\text {b) }}$ & $28)$ \\
M & Fixed-bed reactor & 750 & 77 & this study \\
\hline
\end{tabular}

MBBR: moving bed biofilm reactor; TDAPR: thermophilic down-flow anaerobic packed-bed reactor.

a) Temp. M: mesophilic temperature, Temp. T: thermophilic tenperature.

b) Values calculated from the data reported.

c) Methane production rate when it is assumed that $100 \%$ of acetate was converted to methane.

d) No data available

Table 2 Specific Growth Rates of Aceticlastic Methanogens

\begin{tabular}{lccc}
\hline \multicolumn{1}{c}{ Name of methanogens } & Temp. $\left[{ }^{\circ} \mathrm{C}\right]$ & Specific growth rate $\left[\mathrm{h}^{-1}\right]$ & Reference \\
\hline Thermophilic acetate-utilizing methanogen (TAM) & 60 & 0.032 & $29)$ \\
Methanothrix sp. & 58 & 0.022 & $30)$ \\
Methanosaeta soehngenii & 37 & 0.008 & $23)$ \\
Methanosarcina sp. strain 227 & 35 & $0.01-0.02$ & $31)$ \\
Methanosarcina sp. strain TM-1 & 58 & 0.058 & $32)$ \\
Methanosarcina mazei & 30 & $0.059-0.096$ & $33)$ \\
Highly enriched Methanosaeta sp. strain $\mathrm{H}_{\mathrm{A}}(\mathrm{NaCl} \mathrm{3.0 \% )}$ & 37 & 0.036 & $20)$ \\
Methanogens from marine sludge $(\mathrm{NaCl} 3.0 \%)$ & 37 & 0.152 & this study \\
\hline
\end{tabular}

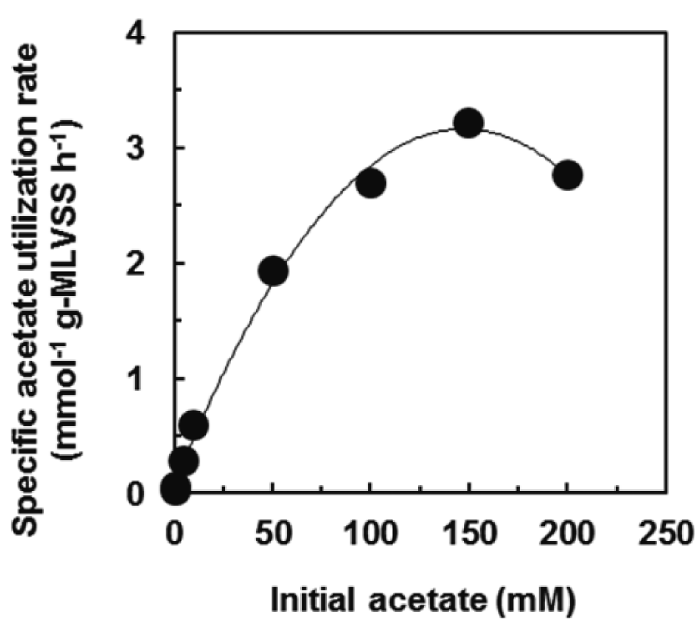

Fig. 4 Acetate Utilization by Acclimated Sludge in the Fixed-bed Reactor at Various Initial Acetate Concentrations

Agency.

\section{References}

1) Rinzema, A., Vanlier, J., Lettinga, G., Enzyme Microb. Technol., 10, 24 (1988).

2) Lakaniemi, A. M., Hulatt, C. J., Thomas, D. N., Tuovinen, O. H., Puhakka, J. A., Biotechnol. Biofuels, 4, 12 (2011).

3) Liu Y. T., Boone, D. R., Bioresour. Technol., 35, 271 (1991).

4) Miura, T., Kita, A., Okamura, Y., Aki, T., Matsumura, Y., Tajima, T., Kato, J., Nakashimada, Y., Bioresour. Technol., 169, 362 (2014)

\section{(A) Granule-like}

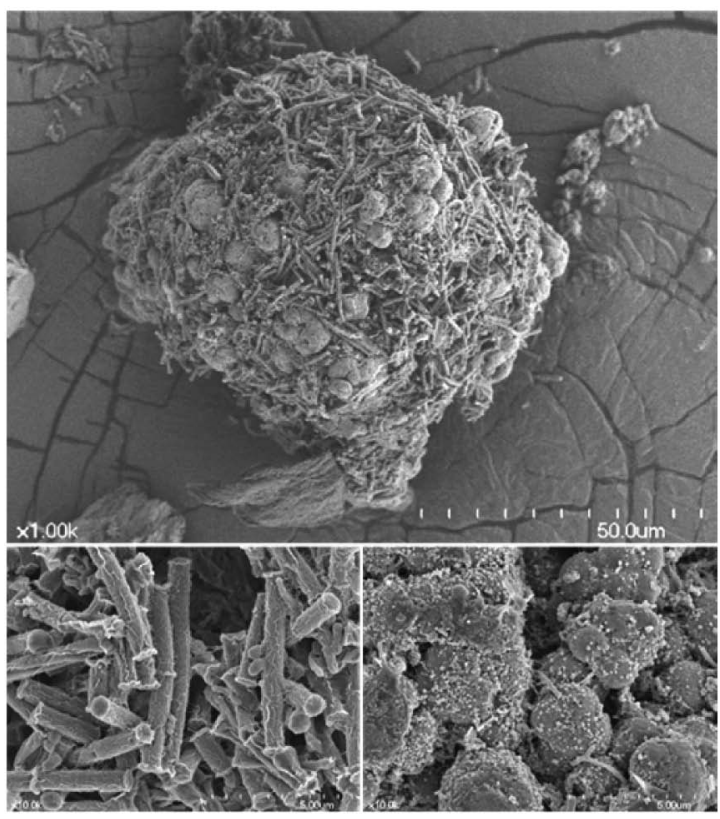

(B) Methanosaeta-like

(C) Methanosarcina-like

Fig. 5 SEM Photographs of a Granule-like Structure (A), Filamentous Methanosaeta-like (B), and Coccoid Methanosarcina-like Microorganisms (C) in the Sediment from the Fixed-batch Reactor

5) Mottet, A., Habouzit, F., Steyer, J. P., Bioresour. Technol., 158, 300 (2014).

6) Shi, X. Q., Lefebvre, O., Ng, K. K., Ng, H. Y., Bioresour. 
Technol., 153, 79 (2014).

7) Vallero, M. V. G., Pol, L. W. H., Lettinga, G., Lens, P. N. L., Water Res., 37, 2269 (2003).

8) Winter, J., Wolfe, R. S., Arch. Microbiol., 121, 97 (1979).

9) Hao, L.-P., Lue, F., He, P.-J., Li, L., Shao, L.-M., Environ. Sci. Technol., 45, 508 (2011).

10) Yang, S.-L., Tang, Y.-Q., Gou, M., Jiang, X., Appl. Microbiol. Biotechnol., 99, 3269 (2015).

11) Mackie, R. I., Bryant, M. P., Appl. Environ. Microbiol., 41, 1363 (1981).

12) Smith, P. H., Mah, R. A., Appl. Microbiol., 14, 368 (1966).

13) Mountfort, D. O., Asher, R. A., Appl. Environ. Microbiol., 35, 648 (1978).

14) Sun, L., Muller, B., Westerholm, M., Schnurer, A., $J$. Biotechnol., 171, 39 (2014).

15) Smith, K. S., Ingram-Smith, C., Trends Microbiol., 15, 150 (2007).

16) Nizami, A. S., Murphy, J. D., Renew. Sust. Energ. Rev., 14, 1558 (2010).

17) Demirer, G. N., Chen, S., Process Biochem., 40, 3542 (2005).

18) Chowdhury, P., Viraraghavan, T., Srinivasan, A., Bioresour. Technol., 101, 439 (2010).

19) Roesijadi, G., Jones, S. B., Snowden-Swan, L. J., Zhu, Y., "Macroalgae as a Biomass Feedstock: A Preliminary Analysis (PNNL-19944)," Pacific Northwest National Laboratory, Richland, WA (2010).

20) Kita, A., Suehira, K., Miura, T., Okamura, Y., Aki, T., Matsumura, Y., Tajima, T., Kato, J., Nishio, N., Nakashimada,
Y., J. Biosci. Bioeng., in press (doi:10.1016/j.jbiosc. 2015.05.018).

21) Takeno, K., Nakashimada, Y., Kakizono, T., Nishio, N., Appl. Microbiol. Biotechnol., 56, 280 (2001).

22) Fukuzaki, S., Nishio, N., Nagai, S., Appl. Environ. Microbiol., 56, 3158 (1990).

23) Huser, B. A., Wuhrmann, K., Zehnder, A. J. B., Arch. Microbiol., 132, 1 (1982).

24) Sowers, K. R., Baron, S. F., Ferry, J. G., Appl. Environ. Microbiol., 47, 971 (1984).

25) De Vrieze, J., Hennebel, T., Boon, N., Verstraete, W., Bioresour. Technol., 112, 1 (2012).

26) Spanheimer, R., Mueller, V., Arch. Microbiol., 190, 271 (2008).

27) Mori, K., Iino, T., Suzuki, K.-I., Yamaguchi, K., Kamagata, Y., Appl. Environ. Microbiol., 78, 3416 (2012).

28) Tatara, M., Makiuchi, T., Ueno, Y., Goto, M., Sode, K., Bioresour. Technol., 99, 4786 (2008).

29) Ahring, B. K., Westermann, P., Appl. Environ. Microbiol., 53, 434 (1987).

30) Zinder, S. H., Cardwell, S. C., Anguish, T., Lee, M., Koch, M., Appl. Environ. Microbiol., 47, 796 (1984).

31) Smith, M. R., Mah, R. A., Appl. Environ. Microbiol., 39, 993 (1980).

32) Zinder, S. H., Mah, R. A., Appl. Environ. Microbiol., 38, 996 (1979).

33) Rajoka, M. I., Tabassum, R., Malik, K. A., Bioresour. Technol., 67, 305 (1999).

\title{
要旨
}

\section{海洋底泥に固定化された酢酸資化メタノジェンを用いた塩環境下での酢酸からの高効率メタン発酵}

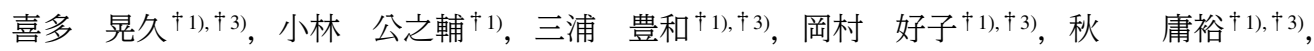

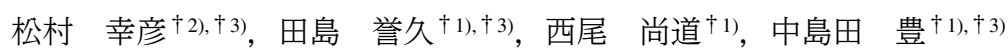 \\ †1) 広島大学大学院先端物質科学研究科分子生命機能科学専攻, 739-8530 広島県東広島市鏡山1-3-1 \\ †2) 広島大学大学院工学研究院エネルギー・環境部門, 739-8527 広島県東広島市鏡山1-4-1 \\ †3) 科学技術振興機構 CREST, 102-0076 東京都千代田区五番町7
}

海洋底泥を固定化担体および而塩性酢酸資化性メタン生成菌 源として，3\%の塩濃度条件下での固定床型リアクターを用い た酥酸からのメタンの超高速生産を試みた。連続培養試験にお いて, $16.2 \mathrm{~d}^{-1}$ の希䣋率および $3 \%$ の塩濃度下で $750 \mathrm{mM} \mathrm{d}^{-1}$ の 最大メ夕ン生産効率が得られた。その際の酢酸除去率は $77 \%$ であった。走査型電子顕微鏡による観察の結果, グラニュール
の形成および Methanosaeta 様の糸状微生物, Methanosarcina 様 の球菌が確認された。これらの結果から, 海洋底泥は耐塩性义 タン発酵の微生物源としてだけではなく, 酢酸からの超高速メ タン生産を可能とする固定化担体としても優れていることが示 唆された。 